\title{
Maternal Factors Associated with Low Birth Weight in Term Neonates: A Case-controlled Study
}

\section{Fatores Maternos Associados ao Baixo peso de Nascimento em Neonatos a Termo: um Estudo de Caso-controle}

\author{
Eduardo Mahecha-Reyes ${ }^{1}$ Carlos Fernando Grillo-Ardila ${ }^{2}$ \\ ${ }^{1}$ Department of Health Sciences, Universidad Surcolombiana, \\ Address for correspondence Eduardo Mahecha-Reyes, Departamento \\ Neiva, Colombia \\ 2 Department of Obstetrics and Gynecology, Universidad Nacional de \\ de Ciencias Médicas, Universidad Surcolombiana, Carrera 20 No. 5 B-
} Colombia, Bogotá, Colombia

Rev Bras Ginecol Obstet 2018;40:444-449.

\begin{abstract}
Keywords

- case-controlled studies

- developing countries

- low birth weight

- risk factors

- term birth
\end{abstract}

\section{Resumo}

Objective To identify maternal factors associated with the presence of low birth weight in term neonates.

Methods Matched hospital-based case-controlled study performed in a high complexity institution located in the city of Neiva, Colombia. The study included women with term gestation and singleton live fetuses. Patients with prior diseases, coming from other regions, with pregnancy resulting from assisted reproduction, or with a diagnosis of fetal abnormality or aneuploidy were excluded. Low birth weight was the dependent variable, and the independent variables that were analyzed were maternal sociodemographic and clinical characteristics. Adjusted and non-adjusted odds ratios (aOR and OR) together with the $95 \%$ confidence intervals $(95 \% \mathrm{Cl}$ ) were reported.

Results The study included 270 participants ( 90 cases and 180 controls). Controlling for maternal age, educational level, socioeconomic and civil status, social security and the presence of maternal disease during gestation, it was found that weight gain (aOR 0.77, $95 \% \mathrm{Cl} 0.70-0.85$ ) and the absence of prenatal care (aOR 8.20, 95\% Cl 3.22-20.87) were among the factors associated with low birth weight.

Conclusions The absence of weight gain and of prenatal care are factors associated with the presence of low birth weight in term neonates and should be considered in clinical practice.

Objetivo Identificar fatores maternos associados à presença de baixo peso ao nascer em neonatos a termo.

Métodos Estudo de caso-controle realizado em uma instituição de alta complexidade localizada na cidade de Neiva, Colômbia. O estudo incluiu mulheres com gestação a termo e fetos vivos únicos. Pacientes com doenças prévias, provenientes de outras regiões, com gravidez resultante de reprodução assistida, ou com diagnóstico de anormalidade fetal ou aneuploidia foram excluídos. O baixo peso ao nascer foi a variável received

April 2, 2018

accepted

May 28, 2018
DOI https://doi.org/

$10.1055 / \mathrm{s}-0038-1667341$. ISSN 0100-7203.
Copyright $\odot 2018$ by Thieme Revinter

Publicações Ltda, Rio de Janeiro, Brazil
License terms

(c) (1) 
Palavras-chave

- estudos de casocontrole

- países em desenvolvimento

- baixo peso ao nascer

- fatores de risco

- termo de nascimento dependente, e as variáveis independentes analisadas foram as características sociodemográficas e clínicas maternas. Razões de chance ajustadas e não ajustadas (RCa e RC) juntamente com os intervalos de confiança de $95 \%$ (IC 95\%) foram relatadas. Resultados $\mathrm{O}$ estudo incluiu 270 participantes (90 casos e 180 controles). Controlando a idade materna, nível escolar, socioeconômico e civil, segurança social e a presença de doença materna durante a gestação, constatou-se que ganho de peso (RCa 0,77, IC 95\% 0,70-0,85) e ausência de pré-natal (RCa 8,20, IC 95\% 3,22-20,87) estavam entre os fatores associados ao baixo peso ao nascer.

Conclusão As ausências de ganho ponderal e de pré-natal são fatores associados à presença de baixo peso ao nascer em recém-nascidos a termo e devem ser considerados na prática clínica.

\section{Introduction}

The World Health Organization (WHO) defines low birth weight as weight at birth lower than 2,500 g. ${ }^{1}$ However, birth weight is determined by two critical considerations: gestational age at delivery and the rate of fetal growth. ${ }^{2}$ Consequently, low weight determining factors may differ between a preterm and a term neonate because, in the former, low weight is usually explained by prematurity, while in the latter, it is result of intrinsic and/or extrinsic factors that impact on developmental potential. ${ }^{1,2}$ Therefore, it comes as no surprise that low birth weight neonates have a worse prognosis in terms of survival and neural development. $^{3}$

According to The United Nations International Children's Emergency Fund (UNICEF), more than 20 million infants are born with low weight in the world, accounting for $15 \%$ of all births. Of these, more than $95 \%$ are born in middle- and lowincome countries, with those in Asia, Africa and Latin America being the most frequently affected. ${ }^{4}$ Prevalence in these countries is twice as high as the ones observed in developed countries, reflecting the inequities faced by pregnant women in those regions of the world where adverse conditions, such as malnutrition, poor weight gain, anemia or pregnancyrelated disorders, like hypertension, possibly explain the observed frequencies. ${ }^{1,5}$

Preventing low birth weight is a public health priority, and one of the goals for the new millennium. ${ }^{4}$ Reducing the frequency of low birth weight pregnancies could have a positive impact on infant mortality in middle- and lowincome countries, which are the ones with the largest shortage of resources required for the care of these neonates. ${ }^{4}$ Consequently, efforts aimed at identifying risk factors associated with this condition are mandatory. ${ }^{6}$ Knowledge of the factors that influence low birth weight will contribute to the timely identification and early intervention in pregnant women at risk. ${ }^{7}$ Therefore, the objective of this study was to identify maternal factors associated with the presence of low birth weight in term neonates born in 2015 and 2016 in a high complex institution in the city of Neiva, Colombia.

\section{Methods}

This was a retrospective, analytical case-controlled study conducted at Hospital Universitario Hernando Moncaleano Perdomo, a high complexity institution located in the city of Neiva, serving the population of southwestern Colombia.

The subjects included were women with term gestations and singleton live fetuses, who were treated at the participating institution between January 2015 and October 2016. Patients with any existing diseases before pregnancy (such as hypertensive vascular disease, nephropathy, diabetes mellitus, thrombophilia, heart, neurodegenerative, cancer or autoimmune diseases), coming from a different geographic area, with a gestation resulting from assisted reproduction, or with a confirmed diagnosis of major fetal abnormality or aneuploidy were excluded.

Cases were defined as live neonates with a weight at birth under 2,500 $\mathrm{g}$ and a gestational age of 37 weeks of gestation or more. Gestational age was estimated based on the last menstrual period or ultrasound. Term neonates weighing $2,500 \mathrm{~g}$ or more were considered controls. The cases were identified using entries in the database of the epidemiological surveillance system corresponding to low birth weight, and the information was compared with the newborn vital statistics registry. In Colombia, the birth of a neonate with low weight is a public health event and reporting is mandatory. Controls were selected from the vital statistics database of the participating institution and the quality of the data was verified by means of a clinical record review. The cases and controls were selected by random sampling until the required sample size was completed.

Sample size estimation was based on the approach suggested by Freeman, consisting of the use of the event of interest by variable. In this way, the sample size for a non-conditioned logistic regression was determined to be $10^{*}(\mathrm{k}+1)$, in which $\mathrm{k}$ is the number of study variables. ${ }^{8}$ According to this principle, and given that for this study, a priori, research into the potential association between low birth weight and maternal age, weight gain, educational level, socioeconomic and marital status, social security, gestational age at the start of prenatal care, and the presence of maternal disease during gestation had been proposed, at least 90 cases and an equal number of controls 
were required $(n=180)$. However, it was decided to select 2 controls for every case to increase the power. Thus, the required sample size for the study was 270 participants.

The data were analyzed using the Stata software package, version 15 (StataCorp. College Station, TX, USA). Descriptive statistics were applied to clinical and sociodemographic variables. The central trend and scatter were estimated for continuous data, and proportions and frequency measurements were used for qualitative data. The frequency and distribution were examined for categorical variables, and a normal distribution and variance homogeneity were analyzed for continuous variables. For the categorical variables, differences between cases and controls were tested using the Fisher exact test or the Pearson Chi-squared test. Continuous variables were compared using the Mann-Whitney test, given the absence of a normal distribution. A univariate logistic regression was applied to assess the association between candidate variables and low birth weight.

A multivariate logistic model was built to incorporate the clinical and sociodemographic variables mentioned above. A non-conditional logistic regression was performed to adjust for the presence of potential confounding factors, the predictive ability of the model was estimated, and the goodness of the adjustment was assessed using McFadden $\mathrm{R}^{2}$. However, to identify the most parsimonious model, a second analysis was performed using the stepwise backward approach, to which the Bonferroni correction was applied, thus adjusting the significance level. ${ }^{9}$ For the second model, the independent variables associated with the outcome of interest were preserved, with a significance level lower than $0.005 .{ }^{9}$ Confidence intervals were estimated, and adjusted and nonadjusted odds ratios (aOR and OR) are presented as the association measure. The study protocol was approved by the Ethics Committee of the participating institution (Reference 009-006).

\section{Results}

There were 4,882 term deliveries in the participating institution during the study period. Of this total, 3.0\% were neonates with low birth weight for gestational age. Once the target population was identified, the cases and controls were selected by random sampling until the required sample size was completed. For each selected case and control, we verify the inclusion and exclusion criteria before their incorporation into study. Finally, the study population was then assembled and consisted of 90 cases and 180 controls.

In terms of the characteristics of the population analyzed, the mean age was 23 years, and there was a predominance of secondary education level, low socioeconomic bracket, free union as marital status, affiliation with the subsidized healthcare regime, and urban place of residence. Regarding clinical characteristics, $54.0 \%$ of the women were multiparous and $61.4 \%$ had attended 5 or more prenatal care visits; $62.9 \%$ were vaginal deliveries, the mean gestational age at the time of delivery was 38.4 weeks, and the mean birth weight was 2,965 $\mathrm{g}$ ( $\mathrm{SD} \pm 552 \mathrm{~g})$. - Table 1 summarizes the baseline characteristics of the population by group (cases or controls).
Table 1 Description of the sociodemographic and clinical characteristics of cases and controls

\begin{tabular}{|c|c|c|c|c|c|}
\hline \multirow[t]{2}{*}{$\begin{array}{l}\text { Variable } \\
\text { Mean }\end{array}$} & \multicolumn{2}{|c|}{$\begin{array}{l}\text { Cases } \\
(n=90)\end{array}$} & \multicolumn{2}{|c|}{$\begin{array}{l}\text { Controls } \\
(n=180)\end{array}$} & \multirow[t]{2}{*}{$p$ value } \\
\hline & Mean & Range & Mean & Range & \\
\hline Age & 22.0 & $(14-42)$ & 24.1 & $(13-45)$ & $p=0.00^{\mathrm{a}}$ \\
\hline $\begin{array}{l}\text { Variable } \\
\text { measured }\end{array}$ & \multicolumn{2}{|l|}{$\mathrm{n}(\%)$} & \multicolumn{2}{|l|}{$\mathrm{n}(\%)$} & $p$ value \\
\hline \multicolumn{5}{|c|}{ Educational level } & \multirow[t]{5}{*}{$p=0.29^{b}$} \\
\hline None & \multicolumn{2}{|c|}{$0(0.00)$} & \multicolumn{2}{|c|}{$1(0.56)$} & \\
\hline Primary & \multicolumn{2}{|c|}{$20(22.22)$} & \multicolumn{2}{|c|}{$30(16.67)$} & \\
\hline Secondary & \multicolumn{2}{|c|}{$61(67.78)$} & \multicolumn{2}{|c|}{$138(76.6)$} & \\
\hline $\begin{array}{l}\text { Technical/ } \\
\text { University }\end{array}$ & \multicolumn{2}{|c|}{$9(10.00)$} & \multicolumn{2}{|c|}{$11(6.11)$} & \\
\hline \multicolumn{5}{|c|}{ Socioeconomic status } & \multirow[t]{4}{*}{$p=0.00^{b}$} \\
\hline Low & \multicolumn{2}{|c|}{$58(64.44)$} & \multicolumn{2}{|c|}{$139(77.22)$} & \\
\hline Medium & \multicolumn{2}{|c|}{$27(30.00)$} & \multicolumn{2}{|c|}{$40(22.22)$} & \\
\hline High & \multicolumn{2}{|c|}{$5(5.56)$} & \multicolumn{2}{|c|}{$1(0.56)$} & \\
\hline \multicolumn{5}{|l|}{ Marital status } & \multirow[t]{4}{*}{$p=0.89^{c}$} \\
\hline Single & \multicolumn{2}{|c|}{$39(43.33)$} & \multicolumn{2}{|c|}{$79(43.89)$} & \\
\hline Free union & \multicolumn{2}{|c|}{$43(47.78)$} & $88(48$ & 89) & \\
\hline Married & $8(8.8 \mathrm{~s}$ & & $13(7.2$ & & \\
\hline Social security & & & & & $p=0.52^{\mathrm{b}}$ \\
\hline Subsidized & $83(92$ & 22) & $154(8$ & $5.56)$ & \\
\hline $\begin{array}{l}\text { Contributive/ } \\
\text { Special }\end{array}$ & $6(6.67$ & & $23(12$ & 78) & \\
\hline $\begin{array}{l}\text { No payment } \\
\text { capability }\end{array}$ & $1(1.11$ & & $3(1.67$ & & \\
\hline Place of resider & & & & & $p=0.37^{c}$ \\
\hline Urban & $64(71$ & 11) & $137(7$ & $5.11)$ & \\
\hline Rural & $26(28$ & 89) & $43(23$ & 89) & \\
\hline Gestational age & at the $s$ & art of pren & atal care & & $p=0.00^{c}$ \\
\hline First trimester & $30(33$ & 33) & $86(47$ & 78) & \\
\hline $\begin{array}{l}\text { Second } \\
\text { trimester }\end{array}$ & $16(17$ & 78) & $48(26$ & 67) & \\
\hline $\begin{array}{l}\text { Third } \\
\text { trimester }\end{array}$ & $20(22$ & 22) & $39(21$ & 67) & \\
\hline $\begin{array}{l}\text { No prenatal } \\
\text { care }\end{array}$ & $24(26$ & 67) & $7(3.89$ & & \\
\hline Disease during & pregnan & & & & $p=0.00^{c}$ \\
\hline No & $58(64$ & 44) & $143(7$ & $9.44)$ & \\
\hline Yes & $32(35$ & 56) & $37(20$ & 56) & \\
\hline Sex of the new & orn & & & & $p=0.79^{c}$ \\
\hline Female & $48(53$ & 33) & $93(51$ & 67) & \\
\hline Male & $42(46$ & 67) & $87(48$ & 33) & \\
\hline
\end{tabular}

${ }^{a}$ Mann-Whitney test for mean differences.

${ }^{b}$ Fisher exact test.

'Pearson Chi-squared test.

The two groups were similar, except in terms of socioeconomic status, gestational age at the start of prenatal care, and the presence of disease during pregnancy. - Table 2 summarizes the frequency and type of disease by group (cases or controls). 
Table 2 Frequency and type of disease during pregnancy by group (cases or controls)

\begin{tabular}{|c|c|c|c|}
\hline \multirow[t]{2}{*}{$\begin{array}{l}\text { Disease during } \\
\text { pregnancy }\end{array}$} & $\begin{array}{l}\text { Cases } \\
(\mathrm{n}=90)\end{array}$ & $\begin{array}{l}\text { Controls } \\
(n=180)\end{array}$ & \multirow[t]{2}{*}{$p$-value } \\
\hline & n (\%) & $\mathrm{n}(\%)$ & \\
\hline No & $58(64.4)$ & $143(79.4)$ & \multirow[t]{10}{*}{$p=0.00^{a}$} \\
\hline Yes & $32(35.5)$ & $37(20.5)$ & \\
\hline \multicolumn{3}{|l|}{ By type } & \\
\hline $\begin{array}{l}\text { Hypertensive } \\
\text { disorder }\end{array}$ & $19(21.1)$ & $17(9.4)$ & \\
\hline Perinatal infection & $6(6.6)$ & $7(3.8)$ & \\
\hline Endocrine disease & $2(2.2)$ & $5(2.7)$ & \\
\hline $\begin{array}{l}\text { Placental-amniotic } \\
\text { fluid disease }\end{array}$ & $4(4.4)$ & $2(1.1)$ & \\
\hline Anemia & $0(0.0)$ & $4(2.2)$ & \\
\hline $\begin{array}{l}\text { Neurological } \\
\text { condition }\end{array}$ & $1(1.1)$ & $1(0.05)$ & \\
\hline Pulmonary disease & $0(0.0)$ & $1(0.05)$ & \\
\hline
\end{tabular}

${ }^{\text {aPearson }}$ Chi-squared test.

Maternal age was significantly different between the groups, although the difference observed was not clinically relevant. For the neonates (data not shown), the mean gestational age at the time of birth was 37.9 weeks for the cases and 39.0 weeks for the controls, while the average weight was 2,328 $\mathrm{g}$ (SD $\pm 166 \mathrm{~g}$ ) for the cases and 3,282 $\mathrm{g}(\mathrm{SD} \pm 371 \mathrm{~g})$ for the controls. Of the lowweight neonates, $78.2 \%$ were admitted to the kangaroo program and $3.2 \%$ to the neonatal intensive care unit.

The univariate logistic regression revealed that maternal age (OR 0.94, 95\% CI 0.90-0.98) and weight gain during pregnancy (OR $0.77,95 \% \mathrm{CI} 0.70-0.84$ ) behaved as protective factors. The risk was also significantly lower depending on the educational level of the mother (technical/university education OR $0.10,95 \% \mathrm{CI} 0.01-0.83$ ). On the other hand, the absence of prenatal care (OR 9.82, 95\% CI 3.84-25.13) and the presence of maternal disease during pregnancy (OR 2.13, 95\% CI 1.21-3.74) behaved as risk factors. - Table 3 shows the

Table 3 Multivariate analysis of maternal factors associated with low birth weight

\begin{tabular}{|l|l|l|}
\hline Variables & $\begin{array}{l}\text { First model }^{\mathrm{a}} \\
\text { aOR }(95 \% \mathrm{CI})^{\mathrm{b}}\end{array}$ & $\begin{array}{l}\text { Second model }^{\mathrm{a}} \\
\text { aOR }(95 \% \mathrm{Cl})\end{array}$ \\
\hline Maternal age & $0.91(0.86-.96)$ & $3^{\mathrm{c}}$ \\
\hline Weight gain & $0.77(0.69-0.86)$ & $0.77(0.70-0.85)$ \\
\hline $\begin{array}{l}\text { Absence of } \\
\text { prenatal care }\end{array}$ & $10.67(3.49-32.64)$ & $8.20(3.22-20.87)$ \\
\hline
\end{tabular}

Abbreviations: aOR, adjusted odds ratio; $95 \% \mathrm{Cl}, 95 \%$ confidence interval.

${ }^{a}$ Adjusted for variables: level of schooling, socioeconomic bracket, marital status, social security and the presence of maternal disease.

${ }^{b}$ Adjusted odds ratios together with the $95 \%$ confidence intervals;

'Variable removed from the model: $p$ of 0.01 but greater than 0.005 . results of the logistic regression, together with their respective aOR and $\mathrm{CI}$.

Following this exploration, a multivariate analysis was performed with the main goal of identifying the clinical or sociodemographic characteristics that could be linked to the presence of low birth weight. An initial model was built, ratifying the role played by maternal age, low weight gain and absence of prenatal care. When the goodness of the adjustment was assessed, the McFadden $\mathrm{R}^{2}$ was 0.27 , with a predictive capacity of $80.3 \%$, reflecting a high percentage of correctness. ${ }^{10}$ However, when the second analysis was performed, only the absence of prenatal care and of adequate weight gain continued to be statistically significant. This time, the McFadden $\mathrm{R}^{2}$ was 0.17 , with a predictive capacity of $72.4 \%$, showing an acceptable percentage of correctness. ${ }^{10}$

\section{Discussion}

Low birth weight is one of the most important determinants of infant morbidity and mortality because it increases the frequency of adverse perinatal outcomes. ${ }^{11}$ Identification of factors that may have an impact on potential fetal growth is an excellent opportunity to have an impact on the health conditions of the population. ${ }^{12}$

There were 4,882 term live births during the observation period, of which $3.0 \%$ were low birth weight neonates. The population consisted mainly of young, single mothers with low socioeconomic and education levels, living in urban areas. Only $43 \%$ of the women started prenatal care during the first trimester of gestation. In our study, the prevalence of low birth weight was similar to that reported in other Latin American countries, but substantially lower than the one described for countries in Southeast Asia. ${ }^{13-19}$ These differences could be explained, at least in part, by the rate of fetal growth, genetic factors and the presence of other extrinsic circumstances not related to pregnancy. ${ }^{7,20}$

On the other hand, regarding the multivariate analysis, it revealed that maternal weight gain (aOR $0.77,95 \% \mathrm{CI} 0.70-0.85$ ) behaves as a protective factor, while the absence of prenatal care (aOR 8.20,95\% CI 3.22-20.87) increases the probability of an unfavorable outcome. Our findings are similar to those documented in the literature. Observational studies have shown the association between maternal weight gain and neonatal birth weight. ${ }^{7}$ For example, it is known that infants born to mothers with poor weight gain are at a higher risk of being small for gestational age, while those born to mothers with substantial weight gain have a higher probability of being large. ${ }^{21}$ This association is consistent in low, middle and highincome countries alike. ${ }^{22}$

Regarding poor prenatal care or absence thereof, the observed association emerges in populations from middle and low-income countries, and it is not completely clear in developed countries. ${ }^{7,23-27}$ The potential explanation is that early and adequate prenatal care could be of greater benefit in women with less favorable conditions, where the implementation of this intervention could help address harmful behaviors that affect fetal growth (for example, smoking), early detection and treatment of diseases affecting gestation 
(such as anemia, malnutrition), and promote healthy lifestyle habits that can have a positive impact on the fetal environment. ${ }^{20,28}$

Finally, although maternal age was eliminated as a variable in the second model, the observed association seems plausible, is clinically relevant, and has been documented in other studies. $^{29}$ This association could be explained by the conditions of inequity and disadvantage faced by teen mothers when compared with older women. Therefore, not surprisingly, the risk of low birth weight decreases as a function of older maternal age, given that older women may have better socioeconomic conditions and find themselves less at a social disadvantage. ${ }^{30}$ It is no secret that racial segregation and deprivation are associated with low birth weight. $^{31}$ Notwithstanding, it needs to be said that this conclusion must be interpreted cautiously, given that the finding could be the result of multiple comparisons.

This study has some strengths, starting with the appropriate and widely accepted definition of the cases, which are considered representative of the study population because all the eligible neonates with the outcome of interest were included. In Colombia, reporting of low birth weight events is mandatory, hence there is a low probability of having missed a case. ${ }^{32,33}$ On the other hand, given matched and independent data recording, there is confidence regarding the reliability of the data and a low probability of error in the definition of cases and controls.

Case-controlled comparability was achieved by means of the design and the analysis. ${ }^{34}$ In the design, stringent inclusion and exclusion criteria were used in an attempt to arrive at a relatively homogenous population. In the analysis, a mathematical model was used to adjust for the presence of confounding factors. Although it is true that excluding the presence of residual confounding factors is not feasible, given the nature of the design, the importance and number of the variables considered allows, in some way, for acceptable case-controlled comparability. ${ }^{35}$ Finally, the other strength of this study is that exposure was proven through entry in the clinical record and in the vital statistics database of the Health Secretariat, reducing the risk of poor classification. ${ }^{35}$

This study also has weaknesses. The subjects used as controls came from the same institution and not from the community, making the study prone to selection bias (Berkson fallacy) because, given the origin of the controls, they could be more prone to having certain factors associated with low birth weight, leading to potential distortions for some exposure-disease associations. ${ }^{35}$ Sample size is yet another weakness of the study. Although a design was developed $a$ priori for estimating sample size, the critical assessment of the confidence intervals points to some degree of inaccuracy. ${ }^{36}$

Despite its limitations, this study has many practical implications. First, it highlights the need to ensure adequate weight gain during pregnancy. This is important because adequate weight gain during gestation behaves as an indirect indicator of good nutritional status of the pregnant woman. Secondly, the association observed between poor prenatal care and low birth weight should prompt timely and adequate access to medical care during gestation, especially for vulnerable populations. Medical care during the reproductive period is a valuable opportunity to have a positive impact on health conditions by means of education regarding healthy lifestyle and to ensure early detection and treatment of diseases affecting gestation. Finally, the role of an unfavorable socioeconomic environment could play out in the association observed between maternal age and low birth weight. Hence the need for highlighting the relevance of providing timely and equitable access to quality healthcare systems.

\section{Conclusion}

Based on the findings of this study, low maternal weight gain and untimely initiation of prenatal care are some of the factors known to be associated with the presence of low birth weight in term neonates. On the other hand, the role of maternal age could also be relevant, considering that this association reflects, at least in part, the conditions of poverty and deprivation of the study population. This study, despite its many strengths, has limitations. Therefore, further studies are required to undertake a more extensive evaluation of the maternal factors associated with the presence of low birth weight among term neonates.

\section{Contributions}

Each author participated actively in the planning, execution and conduction of this study. The authors drafted the manuscript, edited, and approved the final, submitted version. None of the authors has a financial or any other conflict of interest.

\section{Conflicts of Interest}

The authors have no conflicts of interest to declare.

\section{Acknowledgments}

We would like to thank to Jose Alferez Carranza (research assistant), who supported information management.

\section{References}

1 Kramer MS. The epidemiology of low birthweight. In: Bhatia J, Bhutta ZA, Kalhan SC, eds. Maternal and Child Nutrition: the First 1,000 Days. Nestlé Nutrition Workshop Series, 74th vol. Basel: Karger; 2013:1-10

2 Barros FC, Barros AJ, Villar J, Matijasevich A, Domingues MR, Victora CG. How many low birthweight babies in low- and middle-income countries are preterm? Rev Saude Publica 2011; 45(03):607-616. Doi: 10.1590/S0034-89102011005000019

3 Keram A, Aljohani A. Low birth weight prevalence, risk factors, outcomes in primary health care setting: a cross-sectional study. Obstet Gynecol Int J. 2016;5(05):176. Doi: 10.15406/ ogij.2016.05.00176

4 United Nations Children's Fund, World Health Organization. Low Birthweight: Country, Regional and Global Estimates. New York, NY: UNICEF; 2004. https://www.unicef.org/publications/index_24840. html. Accessed October 13, 2017

5 Daza V, Jurado W, Duarte D, Gich I, Sierra-Torres CH, DelgadoNoguera M. Bajo peso al nacer: exploración de algunos factores de riesgo en el Hospital Universitario San José en Popayán (Colombia). Rev Colomb Obstet Ginecol 2009;60:124-134 
6 Castaño-Castrillón JJ, Giraldo-Cardona JF, Murillo-Díaz CA, et al. Relación entre peso al nacer y algunas variables biológicas y socioeconómicas de la madre en partos atendidos en un primer nivel de complejidad en la ciudad de Manizales, Colombia, 1999 al 2005. Rev Colomb Obstet Ginecol 2008;59(01):20-25

7 Kramer MS. Determinants of low birth weight: methodological assessment and meta-analysis. Bull World Health Organ 1987;65 (05):663-737

8 Ortega Calvo M, Cayuela Domínguez A. [Unconditioned logistic regression and sample size: a bibliographic review]. Rev Esp Salud Publica 2002;76(02):85-93

9 Louviere JJ, Hensher DA, Swait JD, Adamowicz W. Stated Choice Methods: Analysis and Applications. New York, NY: Cambridge University Press; 2000

10 Kleinbaum DG, Klein M. Logistic Regression: A Self-Learning Text. 3rd ed. New York, NY: Springer; 2011

11 Malin GL, Morris RK, Riley R, Teune MJ, Khan KS. When is birthweight at term abnormally low? A systematic review and meta-analysis of the association and predictive ability of current birthweight standards for neonatal outcomes. BJOG 2014;121 (05):515-526. Doi: 10.1111/1471-0528.12517

12 Risnes KR, Vatten LJ, Baker JL, et al. Birthweight and mortality in adulthood: a systematic review and meta-analysis. Int J Epidemiol 2011;40(03):647-661. Doi: 10.1093/ije/dyq267

13 Villar J, Belizán JM. The relative contribution of prematurity and fetal growth retardation to low birth weight in developing and developed societies. Am J Obstet Gynecol 1982;143(07):793-798. Doi: 10.1016/0002-9378(82)90012-6

14 Silva AA, Barbieri MA, Gomes UA, Bettiol H. Trends in low birth weight: a comparison of two birth cohorts separated by a 15 -year interval in Ribeirão Preto, Brazil. Bull World Health Organ 1998; 76(01):73-84

15 Villar J, Ezcurra EG, de La Fuente VG, Canpodonico I. Preterm delivery syndrome: the unmet need. Res Clin Forums. 1994;16:9-33

16 Arifeen SE, Black RE, Caulfield LE, et al. Infant growth patterns in the slums of Dhaka in relation to birth weight, intrauterine growth retardation, and prematurity. Am J Clin Nutr 2000;72 (04):1010-1017. Doi: 10.1093/ajcn/72.4.1010

17 Bang AT, Baitule SB, Reddy HM, Deshmukh MD, Bang RA. Low birth weight and preterm neonates: can they be managed at home by mother and a trained village health worker? J Perinatol 2005; 25(Suppl 1):S72-S81. Doi: 10.1038/sj.jp.7211276

18 Osendarp SJ, van Raaij JM, Arifeen SE, Wahed M, Baqui AH, Fuchs GJ. A randomized, placebo-controlled trial of the effect of zinc supplementation during pregnancy on pregnancy outcome in Bangladeshi urban poor. Am J Clin Nutr 2000;71(01):114-119. Doi: $10.1093 / \mathrm{ajcn} / 71.1 .114$

19 Christian P, Khatry SK, Katz J, et al. Effects of alternative maternal micronutrient supplements on low birth weight in rural Nepal: double blind randomised community trial. BMJ 2003;326 (7389):571. Doi: 10.1136/bmj.326.7389.571

20 Valero De Bernabé J, Soriano T, Albaladejo R, et al. Risk factors for low birth weight: a review. Eur J Obstet Gynecol Reprod Biol 2004; 116(01):3-15. Doi: 10.1016/j.ejogrb.2004.03.007

21 Goldstein RF, Abell SK, Ranasinha S, et al. Association of gestational weight gain with maternal and infant outcomes: a systematic review and meta-analysis. JAMA 2017;317(21):2207-2225. Doi: 10.1001/jama.2017.3635
22 Han Z, Lutsiv O, Mulla S, Rosen A, Beyene J, McDonald SD; Knowledge Synthesis Group. Low gestational weight gain and the risk of preterm birth and low birthweight: a systematic review and meta-analyses. Acta Obstet Gynecol Scand 2011;90(09): 935-954. Doi: 10.1111/j.1600-0412.2011.01185.x

23 Pinzón-Rondón AM, Gutiérrez-Pinzon V, Madriñan-Navia H, Amin J, Aguilera-Otalvaro P, Hoyos-Martínez A. Low birth weight and prenatal care in Colombia: a cross-sectional study. BMC Pregnancy Childbirth 2015;15:118. Doi: 10.1186/s12884-015-0541-0

24 Bazyar J, Daliri S, Sayehmiri K, Karimi A, Delpisheh A. Assessing the relationship between maternal and neonatal factors and low birth weight in Iran; a systematic review and meta-analysis. J Med Life 2015;8(Spec Iss 4):23-31

25 Vélez-Gómez MP, Barros FC, Echavarría-Restrepo LG, HormazaAngel MP. Prevalencia de bajo peso al nacer y factores maternos asociados: Unidad de atención y protección materno infantil de la clínica universitaria bolivariana, Medellín, Colombia. Rev Colomb Obstet Ginecol 2006;57(04):264-270

26 da Silva TR. Nonbiological maternal risk factor for low birth weight on Latin America: a systematic review of literature with meta-analysis. Einstein (Sao Paulo) 2012;10(03):380-385. Doi: 10.1590/S1679-45082012000300023

27 Rahman MM, Abe SK, Rahman MS, et al. Maternal anemia and risk of adverse birth and health outcomes in low- and middle-income countries: systematic review and meta-analysis. Am J Clin Nutr 2016;103(02):495-504. Doi: 10.3945/ajcn.115.107896

28 ACOG Committee Opinion No 579: Definition of term pregnancy. Obstet Gynecol 2013;122(05):1139-1140. Doi: 10.1097/01. AOG.0000437385.88715.4a

29 Dennis JA, Mollborn S. Young maternal age and low birth weight risk: An exploration of racial/ethnic disparities in the birth outcomes of mothers in the United States. Soc Sci J 2013;50(04): 625-634. Doi: 10.1016/j.soscij.2013.09.008

30 Restrepo-Méndez MC, Lawlor DA, Horta BL, et al. The association of maternal age with birthweight and gestational age: a crosscohort comparison. Paediatr Perinat Epidemiol 2015;29(01): 31-40. Doi: 10.1111/ppe.12162

31 Vos AA, Posthumus AG, Bonsel GJ, Steegers EAP, Denktaş S. Deprived neighborhoods and adverse perinatal outcome: a systematic review and meta-analysis. Acta Obstet Gynecol Scand 2014;93(08):727-740. Doi: 10.1111/aogs.12430

32 Cunningham FG, Leveno KJ, Bloom SL, Hauth JC, Gilstrap L III, Wenstrom KD. Williams Obstetrics. $22^{\text {nd }}$ ed. New York, NY: McGraw-Hill; 2005

33 Ministerio de Salud y Protección Social. Instituto Nacional de Salud. Protocolo de Vigilancia en Salud Publica Bajo Peso al Nacer a Término. Bogotá: Minsalud; 2014. http://www.dadiscartagena. gov.co/images/docs/saludpublica/vigilancia/protocolos/pro_bajo _peso_al_nacer_a_termino_2014.pdf. Accessed March 10, 2017

34 Wells GA, Shea B, O'Connell D, et al. The Newcastle-Ottawa Scale (NOS) for Assessing the Quality of Nonrandomised Studies in MetaAnalyses. 2013. http://www.ohri.ca/programs/clinical_epidemiology/oxford.asp. Accessed March 10, 2017

35 Szklo M, Javier Nieto F. Epidemiología Intermedia: Conceptos y Aplicaciones. Madrid: Díaz de Santos; 2003

36 Guyatt GH, Oxman AD, Kunz R, et al. GRADE guidelines 6. Rating the quality of evidence-imprecision. J Clin Epidemiol 2011;64 (12):1283-1293. Doi: 10.1016/j.jclinepi.2011.01.012 